cooperation with the American Embassy, the British Council, and other institutions, provides information on the academic recognition of foreign degrees, including those provided on-line.

Chantal Kaufman, Head of the Belgian (French Community) ENIC, reported that credential evaluators almost always granted recognition to program articulations; sometimes granted recognition to franchised arrangements, branch campuses, off-shore institutions, and distance education; and almost never granted recognition to nonofficial corporate education or virtual universities.
Transnational education in Lithuania has created new opportunities for students as well as a diversified higher education system. These emerging transnational initiatives have been scrutinized in terms of quality assurance. The "Code of Good Practice in the Provision of Transnational Education," prepared under the auspices of the Council of Europe and UNESCO, proposed basic principles that have helped Lithuanian authorities, credential evaluators, and the academic community to make policy decisions on transnational education establishments and to protect students from fraudulent degrees and qualifications.

\title{
China's Entry into the WTO and Higher Education
}

\section{Yang Rui}

Yang Rui is a lecturer in the Faculty of Education, University of Western Australia, Nedlands, WA 6009, Australia. E-mail: $<$ ryang@ecel.uwa.edu.au>.

$\mathrm{N}$ early all agreements are in place for China to join the WTO after 15 years of trying. While the WTO as it currently stands does not have much to do with education, China's entry will require it to expand its policy of opening up to the outside world, which will have important implications for higher education. Currently, tens of thousands of Chinese parents send their children abroad to be educated, foreign institutions are scrambling for booths in China, and Chinese students are increasingly enrolling in programs offered by foreign institutions within China through distance education, twinning programs, and satellite campuses. Such trends will only be strengthened after the entry. Are these in the best interests of China? It is the purpose of this article to look at the Chinese response to see if the country is well prepared for the possible impacts of entry into the WTO on higher education.

\section{Education Specialists}

It is interesting to note how Chinese education specialists react to the prospect of entry into the WTO. Strangely enough, studies on possible impacts on China's education system have been lacking. Evidence shows that Chinese cademics in education are largely optimistic. Their reasoning is based on two factors: the knowledge economy and the global network. The knowledge industry is seen as a bridge linking education and the economy, increasingly blurring their borders. Knowledge and education, particularly higher education, function as both producer and transmitter and are, therefore, motors for economic growth. Knowledge innovations - the results of education — become the capital to promote economic development, which leads to further educational development.

\section{Many Chinese education researchers hold that entry into the WTO will pro- vide China with a number of education- related opportunities.}

Many Chinese education researchers hold that entry into the WTO will provide China with a number of education-related opportunities. The first lies in the distribution of new knowledge, in which intellectuals will play a major, pioneering role in the newborn Chinese knowledge economy. The second involves the application of that new knowledge. Entry into the WTO will further strengthen China's international educational exchange and help knowledge products expand in the global market. Third, with the production of new knowledge, a more equal environment for Chinese individuals and society can develop, with less of the traditional concentration on social status, gender, nationality, skin color, and age.

Chinese education specialists appear to be quite relaxed regarding WTO entry. In 2000, the authoritative Xinbua Wenzbai reprinted an article by Bao Guoqing, in which the author concludes that China's entry into the WTO and the free trade that ensues will help to establish a cultural and spiritual atmosphere that will foster freedom and will pave the way for individual personal development. According to Bao, the entry will inject the Olympic spirit 
into education, confronting Chinese education with the same (equal) rules of the game, optimize moral discipline and economic behaviors in education, and be a catalyst to bring education in China up to international standards of achievement.

\section{Many Chinese economists openly ex- press the view that education is a com- modity.}

\section{The Message from Economists}

Calls from economists for the marketization of education in China have become louder now that China stands at the threshhold of the trade club. Currently, education stands first among the eight fastest-growing demands in Chinese society. Chinese economists believe there is a gap between supply and demand in education. While government investment in education has appeared to be increasingly inadequate, the efficiency of Chinese education is considered too low, with a teacher-student ratio that is far below the international average.

Chinese economists strongly insist that solutions to the above problem lie in the marketization of education. Given the inadequacy of government investment, new resources need to be found. Economists are confident that China now meets every precondition for the marketization of its education system. First, there exists a huge demand for education. China has a total of 2.6 million secondary school graduates each year, of which only 1.3 million can enter tertiary institutions. Second, waste in education, par- ticularly in the higher education sector, is surprisingly high. Both personnel and material resources are often left unused.

Many Chinese economists openly express the view that education is a commodity. They are highly critical of the fact that education is still burdened with central planning. According to them, there is a tremendous shortage of supply in higher education. An official from the State Planning Commission recently described contemporary Chinese higher education as one of the rare markets in China that represents a good investment and potential economic growth zone. In view of this, private companies are increasingly investing in postcompulsory education.

\section{Conclusion}

China's entry into the WTO will further expose China's higher education system to external forces. Chinese higher education institutions will be required to become competitive internationally. As globalization is influencing universities worldwide through market competition, Chinese universities have tended merely to float with the international tides. With accession to the WTO, Chinese higher education will be more integrated into the international community. The influence of global forces on China's higher education system is only going to increase.

Globalization might create more challenges than opportunities for China. A serious concern is the absence of a well-thought-out plan to cope with the negative aspects of the current, seemingly unstoppable, move toward globalization, of which China's entry into the WTO forms a part. There is danger in failing to make a conscious decision to resist, negotiate, and transform globalization practices.

\section{China's Expansion, Consolidation, and Globalization}

\section{Gerard Postiglione}

Gerard Postiglione is associate professor of education at the University of Hong Kong, where he heads the Centre for the Study of Education in China. Address: Faculty of Education, University of Hong Kong, Pokfulam Rd., Hong Kong, China. E-mail: <gerardap@hkucc.hku.hk>.

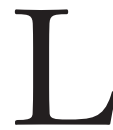

ike other countries that experience a rapid expansion of higher education, China's main challenge is to boost quality at low cost. This is especially true in its nonelite institutions, provincial universities, western region colleges, and the growing number of popularly (privately) run (minban) colleges and universities. Rapid expansion and China's eventual membership in the World Trade Organization makes improving higher education a top priority, and will probably lead to greater cooperation with foreign universities, potentially resulting in further improvement of teaching and scholarship.

\section{Expansion}

China educates 25 percent of the world's students on 1 percent of the world's education budget. The total budgeted government expenditure on education is less than in most developing countries, with only about 13 percent allocated to colleges and universities.

From 1978 to 1996, China's university and college 